Journal Universitas Muhammadiyah Gresik Engineering, Social Science, and Health International Conference (UMGESHIC)

UMGCINMATIC : $1^{\text {st }}$ Rethinking Education during Covid-19 Era: Challange and Innovation

\title{
IMPROVING WORK READINESS ON GRADUATES: THE ROLES OF PSYCHOLOGICAL CAPITAL
}

\author{
Author \\ Rizqi Kurnianing Dewi ${ }^{1}$, Asri Rejeki ${ }^{2}$, Ima Fitri Sholichah ${ }^{3}$ \\ 1,2,3Psychology Faculty, Universitas Muhammadiyah Gresik \\ Email: rizqikurnianingdewi@gmail.com, rejeki.asri@yahoo.com, \\ ima_fitri@umg.ac.id
}

\begin{abstract}
ABSTRAK
The challenge that is often faced in today's working world is the mismatch between the requirements demanded by the company and the competencies of the graduates. When the company conducts recruitment, many graduates are found immature and unprepared for the job, which makes difficult for graduates to be absorbed by large companies, both nationally and internationally. Therefore, graduates need to develop certain capacities beyond their competencies that will enable them to cope with the challenge in the workplace. The aim of this study is to examine how psychological capital affects on work readiness using a sample of 58 graduates in Gresik. This study uses quantitative methods. Data collection methods using the Work Readiness Scale and Psychological Capital Questionnaire. The data analysis used IBM SPSS Statistics 25 program with Simple Linear Regression technique to test the minor hypothesis and Multiple Linear Regression to test the major hypothesis. The results indicate that psychological capital has a significant effect on work readiness and does not have a partial effect. The article concludes by offering implications of the findings for graduates as well as for psychology industry and organization related to work readiness and psychological capital. The number of respondents in this study was not much, so there is a limitations in describing the actual situation. Therefore, it is hoped that further research will be able to use a wider population and sample so that it can be expected that the research results will be better.
\end{abstract}

Keywords: Work Readiness, Psychological Capital, Graduates 


\section{INTRODUCTION}

The current shortage of qualified job applicants is a dilemma. The challenge that is often faced in today's world of work is the mismatch between the requirements demanded by the company and the competence of graduates mastered by Verma et al., (2017:5). One of the HR Recruiter companies in Indonesia said that when the company recruited, it was found that many graduates looked immature and not ready to work. This makes the company not provide opportunities for job applicants who are not in accordance with the company's wishes (depoedu.com accessed December 25, 2020). In line with that, the Minister of Education and Culture of the Republic of Indonesia, Nadiem Anwar Makarim, said that the competence and productivity of graduates or graduates in the world of work is still minimal. Thus, this makes it difficult for highly educated workers to be absorbed by large companies, both on a national and international scale (katadata.co.id accessed on December 9, 2020).

These problems can be used as an indication of the cause of increasing unemployment in Indonesia. The Central Statistics Agency survey in August 2020 reported that the number of unemployed increased by three (3) million people, reaching 9.77 million people since February 2020. Then the number of open unemployment based on the highest educational background (Diploma I/II/III/Academy/University) is known a number of 1,286,464 and 981,203 of them were university graduates. Moreover, in 2020 there was a new global recession due to the COVID-19 health pandemic which had an impact on the economy and the labor market where millions of workers had undergone changes and even mass layoffs occurred (Jobstreet Indonesia Survey 2020:6).

Gresik Regency is one of the cities in East Java which is known as an industrial city. This can be seen from the number of industries recorded at the Central Statistics Agency of East Java Province (2019:257). In Table 1.1 it is known that Gresik Regency is in the 7th rank with the largest number of companies in East Java with a total of 30,396 companies. Until 2020, Gresik Regency has a workforce of 628,952 people. But on the other hand, Gresik Regency recorded a fairly high unemployment rate in East Java Province, ranking 5th after Surabaya, Sidoarjo, Malang, and Jember with 56,265 unemployed people.

The high minimum wage in Gresik Regency is a concern for job seekers, where it is feared that this condition will have an impact where job seekers from outside the region will flock to Gresik Regency to find work. In addition, high wage levels are known to result in a decrease in demand for labor or in other words job providers will ask for fewer workers than before (Susilowati \& Wahyuni, 2019:229).

The high unemployment rate in Gresik Regency is known to be caused by the large number of workers outside Gresik compared to local workers, both in the industrial sector and other sectors. Head of the Gresik Regency Manpower Training and Education Division, Dyah Prasasri Saptorini, said that a number of companies established in the Gresik Regency area were still 
dominated by workers from outside the region. Quoted from the beritagresik.com site, Dyah said that one of the reasons was that local workers were allegedly unable to compete because the quality of existing human resources was still low (https://beritagresik.com/news/peristiwa/12/01/2017/perusahaan-di-gresik-masih-didominasipekerja-luar-daerah.html). The dominance of workers outside the region who work in Gresik Regency illustrates that job applicants lack readiness to work.

Employers' dissatisfaction with these graduates' work readiness performance highlights two important issues. First, knowledge and skills alone are not enough to call graduates "work ready". Second, graduates need to develop certain capacities beyond their competence that will enable them to face challenges in the work environment. There is some literature that discusses that work readiness is not only limited to the possession of certain knowledge and skills, but also must have personal attribute factors, such as personality, problem solving, communication, sociability, maturity, and self-efficacy (Caballero, 2010; Coetzee, 2012).

Psychological capital (PsyCap) is a positive capacity that exists in individuals to develop which is characterized by the construction of self-efficacy, optimism, hope, and resilience. PsyCap as part of personal resources is described as a positive self-evaluation of resilience and refers to an individual's ability to control and influence his environment to succeed (Xanthopoulou et al., 2009:196). Aspects in PsyCap are considered as the basic construction of individual psychological resources to have a higher capacity and play a major role in determining their success in work.

Graduates as prospective workers need to prepare various things to improve their quality in order to compete, be accepted into work, and be successful in their careers. Therefore, other competencies and values are needed that help graduates to be more ready to work, one of which is psychological capital. A strong PsyCap can contribute to improving the work readiness of graduates where one's ability will increase in facing challenges in the work environment (Mashigo, 2014:129).

Because PsyCap is a new theoretical concept, studies related to the concept of work readiness, especially for college graduates, are still limited. In Indonesia, Chandhika and Sarawati (2019:185) in their research show that psychological capital and internship programs significantly shape student work readiness. In addition, psychological capital and organizational support affect the work readiness of college students (Wijayanti, 2019).

The purpose of this study was to determine the effect of PsyCap on work readiness in graduates. This concept is directly related to the findings of previous research which showed that the factors that influence the work readiness of graduates provide evidence that there is a positive and significant relationship between emotional intelligence, sense of coherence, psychological capital, and work readiness (Mashigo 2014:143). Masole \& Dyk (2016:3) show that work readiness is influenced by emotional intelligence and psychological capital, especially on aspects of efficacy, hope, and optimism. In addition, this study also explores the role of each 
aspect in PsyCap in its influence on work readiness.

\section{RESEARCH METHODS}

The researcher uses a research approach in the form of a quantitative method with a predictive correlation research type which shows that knowledge about a variable can be used to predict other variables and to get it regression analysis is generally used (Rahman, 2016:91). The independent variable $(\mathrm{X})$ studied in this study is psychological capital and the dependent variable $(\mathrm{Y})$ studied in this study is work readiness.

\subsection{Participants and procedures}

Study participants were 58 university graduates in 2020-2021 that are domiciled in Gresik district, East Java, Indonesia. Because it is not known certainly about the population, namely graduates who come from various universities and reside in Gresik and there is no supporting data regarding to the number of graduates who have not worked and are applying for jobs, accidental sampling was used. Incidental sampling is a technique in determining samples based on considerations of convenience (Azwar, 2016:151).

Snowball sampling is also used in this study which is a technique for determining the sample which is initially small in number and then enlarges. In the snowball sampling technique, initially one or two people were selected but because the two people had not completed the data, the researchers looked for other people so that they could complete the data (Sugiyono, 2019:134).

Questionnaires were administered to all graduates through online. During the data collection process, graduates were asked to answer statements that had been prepared and in accordance with the actual situation related to their work readiness and PsyCap. Graduates who are known to have graduated in 2020-2021 and do not yet have a job are the main criteria for the subject of this research. Participants are informed that (a) participation is voluntary; and (b) the survey will be managed by the researcher independently and for scientific purposes only.

\subsection{Data collection}

Data was collected online using a web page-based self-completion questionnaire from Google (Google Form).

\subsection{Measures}

a. Work readiness

The measuring tool on this work readiness variable, the researchers compiled a questionnaire based on The Work Readiness Scale which was constructed by Caballero, et al., (2011). A 6-point likert scale $(1=$ very inappropriate, $2=$ inappropriate, $3=$ quite inappropriate, $4=$ quite appropriate, $5=$ appropriate, $6=$ very appropriate) was used to capture graduate responses to items such as "I have equipped myself with the skills required 
by the job I am interested in" and "Making connections with other people is one of my strengths".

\section{b. Psychological capital}

The measuring instrument for this psychological capital variable uses an instrument which has adopted from the Psychological Capital Questionnaire compiled by Luthans (2007:237-238) and modified by the researcher according to the research needs, which is the condition in which a person has not worked and is applying for a job. A 6-point likert scale $(1=$ very inappropriate, $2=$ inappropriate, $3=$ quite inappropriate, $4=$ quite appropriate, 5 = appropriate, $6=$ very appropriate) was used to capture graduate responses to items such as "I feel confident in analyzing problems to find long term solutions" and "Usually I overcome a difficulty in oneway or another".

\subsection{Analyses}

Data analysis method using IBM SPSS 25 program. Simple linear regression test was used to test the major hypotheses. The results of simple linear regression analysis are used to determine whether the estimated value of $y$ can be increased or decreased by increasing or decreasing the score in the variable $x$ (Anwar, 2009:141). In this study, multiple linear regression analysis was also performed to test the minor hypothesis. The application of the multiple regression method has more than one independent variable that affects one dependent variable (Siregar, 2019:405).

\section{RESULTS AND DISCUSSION}

Based on the data in table 4.1, the correlation coefficient value $r=0.724$, it can be interpreted that the level of relationship between psychological capital and work readiness has a strong relationship because it is in the correlation interval 0.60 - 0.799 (Anwar, 2009:104).

In addition, this value indicates that high work readiness is caused by higher PsyCap. On the other hand, the lower the PsyCap a person has, the lower the level of work readiness they have.

Table 1. Simple Linear Regression Analysis Test Results

\begin{tabular}{cccccccc}
\hline $\mathbf{R}$ & $\mathbf{R}$ & \multirow{2}{*}{ Square } & Sig. & $\mathbf{t}$ & $\mathbf{d f}$ & \multicolumn{2}{c}{ Unstandardized Coefficient } \\
$\mathbf{B}$ & Std. Error \\
\hline \multirow{2}{*}{0,724} & 0,524 & \multirow{2}{*}{61.626} & \multirow{2}{*}{0,000} & \multirow{2}{*}{7,850} & \multirow{2}{*}{56} & $\begin{array}{c}129,961 \\
1,442\end{array}$ & $\begin{array}{c}18,714 \\
0,184\end{array}$ \\
\hline
\end{tabular}

\section{$H=$ There is an influence of psychological capital on work readiness}

From the results of the calculations listed in table 4.1, the value of $t$ count $=7.850$ with $\mathrm{df}$ 56. So it can be seen that the t table is 2.0032 . Thus the value of tcount is greater than ttable (tcount $7.850>$ ttable 2.0032). In addition, the value of sig is also known. $p=0.000(0.000<$ 
0.05). The results obtained indicate that the major hypothesis is accepted, meaning that there is an influence between PsyCap on work readiness.

The R Square value of 0.527 indicates that the magnitude of the influence of the psychological capital variable $(\mathrm{X})$ on the work readiness variable $(\mathrm{Y})$ is $52.7 \%$ while the remaining $47.3 \%$ is influenced by other variables not examined in this study.

The findings obtained in this study are PsyCap is an attribute that contributes to the level of work readiness on university graduates. This agrees with Luthans et al. (2007:550) that the stronger PsyCap they have will be beneficial for graduates to develop their ability to evaluate situations positively and increase their chances of success, including in achieving their career goals.

Graduates need to have a PsyCap because the world of work is a new environment full of demands and challenges that are bigger than the university environment. Because PsyCap refers to positive psychological theory which includes 4 positive dimensions, namely self-efficacy, hope, resilience, and optimism, thus enabling graduates to utilize their psychological strengths to survive in the work environment (Kamei, et al., 2018:8).

Table 2. Multiple Linear Regression Analysis Test Results

\begin{tabular}{cccccccc}
\hline PsyCap Components & $\mathbf{R}$ & $\mathbf{R}$ & $\mathbf{F}$ & $\mathbf{d f}$ & $\mathbf{t}$ & Sig. & $\begin{array}{c}\text { Unstandardized } \\
\text { Coefficient } \mathbf{B}\end{array}$ \\
(Constant) & 0,725 & 0,526 & 14,716 & 53 & 5,648 & 0,000 & 125,533 \\
Self-efficacy & & & & & 1,482 & 0,144 & 1,102 \\
Hope & & & & & 1,548 & 0,128 & 1,808 \\
Resilience & & & & & 1,869 & 0,067 & 1,566 \\
Optimism & & & & & 0,719 & 0,475 & 1,694 \\
\hline
\end{tabular}

\section{H1: There is an influence of self efficacy in psychological capital towards work readiness}

The significance value of 0.144 is greater than 0.05 , which means that there is no effect of self-efficacy on the psychological capital variable on the work readiness of college graduates. This shows that the first minor hypothesis which states that there is an influence between selfefficacy on psychological capital variables towards work readiness is rejected.

\section{$\mathrm{H}_{2}$ : There is an influence of hope in psychological capital towards work readiness}

The significance value of 0.128 is greater than 0.05 , which means that there is no effect of hope on the psychological capital variable on the work readiness of college graduates. This shows that the second minor hypothesis which states that there is an influence between the expectation variable on the psychological capital variable on work readiness is rejected.

\section{H3: There is an influence of resilience in psychological capital towards work readiness}

The significance value of 0.067 is greater than 0.05 , which means that there is no effect of resilience on the psychological capital variable on the work readiness of college graduates. This shows that the third minor hypothesis which states that there is an influence between resilience on psychological capital variables on work readiness is rejected. 


\section{H4: There is an influence of optimism in psychological capital towards work readiness}

The significance value of 0.475 is greater than 0.05 , which means that there is no effect of optimism on the psychological capital variable on the work readiness of college graduates. This shows that the fourth minor hypothesis which states that there is an influence between optimism on the psychological capital variable on work readiness is rejected.

Based on the results of multiple linear regression analysis, it is known that the significance value of self-efficacy is 0.144 , expectation is 0.128 , resilience is $0.067 \%$, and optimism is 0.475 . The significance value of the four aspects is more than 0.05 , which means it can be concluded that there is no partial effect between self-efficacy, hope, resilience, and optimism on work readiness, so the minor hypothesis in this study was rejected.

PsyCap is a positive capacity that is useful in helping individuals to develop and is characterized by self-efficacy, hope, resilience, and optimism (Luthans et al. 2007:3). Collaboration between the four constructs in the psycap (self-efficacy, hope, resilience, and optimism) will allow individuals to be more successful in their efforts to achieve a goal compared to only one component (Luthans \& Morgan, 2017:17.25).

Self-efficacy means the increasing confidence that individuals have about their ability to be able to successfully complete challenging tasks or jobs and persist in achieving goals for success, meaning that graduates will increasingly have good work readiness as well. This is in accordance with Bandura's opinion (1997: 116-137) that having self-efficacy tends to help graduates to have high motivation, face uncertain situations that are also accompanied by full of pressure, complete challenges that have been taken, confident in achieving goals which has been set determined, and take the necessary actions to achieve an outcome. Then according to Hubbard (in Utami \& Hudaniah, 2013: 49), individuals who have high self-efficacy are more ready to work, while in the opposite condition individuals who do not have self-confidence will feel restless or anxious in dealing with the world of work later so that in the end they are forced to only work just rely on luck.

Graduates' expectations in work are positive motivations that lead them to success based on desires which then lead to the path to achieving work goals. So in this case it is in accordance with the opinion of Victor H. Vroom (in Wardani 2018:103) that hope can help individuals determine the actions to be taken so that they can achieve a goal or success, which includes estimates of various events that the individual will face. If individuals want something to be achieved and are also accompanied by considerable expectations to achieve it, then they will be highly motivated to make greater efforts. When graduates have the desired goal, namely in the form of work according to their field of expertise, graduates will tend to be more prepared to enter the world of work. So with the hope that it will tend to encourage graduates to master skills so that they have greater work readiness.

Graduates who have high enough resilience will feel more able to rise from failure and take lessons from those failures. The existence of resilience in graduates will have a positive effect on the development of their work readiness skills (Lau et al., 2019:10). As the opinion of Luthans (2011:219), that someone who has resilience will be able to make a firm acceptance of reality, and deep belief.

The existence of optimism will allow graduates to perceive failure as a temporary event 
and not as a personal incapacity, motivated to increase efforts harder in achieving career goals, and tend to persist in the face of obstacles and difficulties (Luthans, 2011:214). So that when graduates have the desired goals and have an optimistic attitude, graduates will tend to be more prepared to face various challenges in entering the world of work.

\section{CONCLUSION}

Based on the discussion and analysis in chapters 1-4, it can be concluded that there is an influence between psychological capital on the work readiness of university graduates. PsyCap is an attribute that contributes to the level of work readiness of college graduates and has $52.4 \%$ impact towards work readiness. There is no partial influence between self-efficacy, hope, resilience, and optimism of PsyCap towards work readiness.

Based on the research process carried out by the researcher, there were several limitations that were encountered and could be taken into consideration in further studies that wish to conduct research on the same variables in this study. The following are limitations in this study, among others:

1. The number of respondents in this study was only 58 subjects, so this is a lack of research to describe the real situation.

2. During the data collection process, the information provided by the respondent was through a questionnaire, which sometimes did not show the respondent's real answer. That is, when the respondent gives an answer by choosing an answer choice from the statements provided, the respondent can give an answer that does not actually happen or is dishonest. So that it can provide an opportunity for respondents to give wrong answers and lead to faking good and faking bad.

\section{REFERENCES}

Anwar, A. (2009). Statistika Untuk Penelitian Pendidikan. In IAIT Press. IAIT Press.

Azwar, S. (2016). Reliabilitas dan Validitas. Pustaka Pelajar.

Badan Pusat Statistik Jawa Timur. (2019). Provinsi Jawa Timur dalam Angka.

Badan Pusat Statistik. (2020). Keadaan Angkatan Kerja di Indonesia Agustus 2020.

Bandura, A. (1997). Self-efficacy: Toward a Unifying Theory of Behavioral Change. Psychological Review, 84(2), 191-215.

Caballero, Catherine L., Walker, A., \& Fuller-Tyszkiewicz, M. (2011). The Work Readiness Scale (WRS): Developing a measure to assess work readiness in college graduates. Journal of Teaching and Learning for Graduate Employability, 2(2), 41-54. https://doi.org/10.21153/jtlge2011vol2no1art552

Caballero, Catherine Lissette, \& Walker, A. (2010). Work readiness in graduate recruitment and selection: A review of current assessment methods. In Journal of Teaching and Learning for Graduate Employability (Vol. 1, Issue 1, pp. 13-25). https://doi.org/10.21153/jtlge2010vol1no1art546

ÇAVUŞ, M. F., \& Kapusuz, A. G. (2014). Psychological Capital: Definition, Components and Effects. British Journal of Education, Society \& Behavioural Science, 5(3), 244-255. https://doi.org/10.9734/BJESBS/2015/12574 
Chandhika, J., \& Saraswati, K. D. H. (2019). Peran Modal Psikologis Dan Dukungan Organisasi Terhadap Kesiapan Kerja Mahasiswa Internship. In Jurnal Muara Ilmu Sosial, Humaniora, dan Seni (Vol. 3, Issue 1, p. 179). https://doi.org/10.24912/jmishumsen.v3i1.3406

Clark, H. (2013). Work Readiness Standards and Benchmarks: The Key to Differentiating America's Workforce and Regaining Global Competitiveness.

Coetzee, M. (2012). Graduateness as a consested idea - Navigating expectations between higher education, employers and graduates. In M. Coetzee, J.-A. Botha, N. Eccles, H. Nienaber, \& N. Holtzhause (Eds.), Developing Student Graduateness and Employability. Knowres Publishing.

Doe, R. (2019). Work Readiness among Graduate Students. In LSU Doctoral Dissertations. https://digitalcommons.lsu.edu/gradschool_dissertations

Jobstreet Indonesia. (2020). COVID-19 Job Report.

Kamei, H., Ferreira, M. C., Valentini, F., Peres, M. F. P., Kamei, P. T., \& Damásio, B. F. (2018). Psychological capital questionnaire-short version (PCQ-12): Evidence of validity of the Brazilian version. Psico-Usf, 23(2), 203-214. doi:10.1590/141382712018230202

Lau, P. L., Wilkins-Yel, K. G., \& Wong, Y. J. (2019). Examining the Indirect Effects of SelfConcept on Work Readiness through Resilience and Career Calling. Journal of Career Development, 20(10), 1-14. https://doi.org/10.1177/0894845319847288

Luthans, F. (2011). Organizational Behavior: an Evidence-Based Approach (12th ed.). McGraw-Hill/Irwin. https://doi.org/10.5005/jp/books/10358_23

Luthans, F., \& Morgan, C. M. Y. (2017). The Annual Review of Organizational Psychology and Organizational Behavior, 4(17), 17.1-17.28.

Luthans, F., \& Morgan, C. M. Y. (2017). The Annual Review OfOrganizational Psychology and Organizational Behavior, 4(17), 17.1-17.28.

Luthans, F., Luthans, K. W., \& Luthans, B. C. (2004). Positive psychological capital: Beyond human and social capital. Business Horizons, 47(1), 45-50.

https://doi.org/10.1016/j.bushor.2003.11.007

Luthans, F., Youssef, C. M., \& Avolio, B. J. (2007). Psychological Capital : Developing the Human. Oxford University Press.

Mashigo, A. C. L. (2014). Factors Influencing Work Readiness of Graduates: an Exploratory Study. http://scholar.sun.ac.za

Masole, L., \& Dyk, G. van. (2016). Factors influencing work readiness of graduates: An exploratory study. Journal of Psychology in Africa, 26(1), 70-73.

https://doi.org/10.1080/14330237.2015.1101284Mason, G., Williams, G., \& Cranmer, S. (2019). Employability skills initiatives in higher education: what effects do they have on graduate labour market outcomes? Education Economics, 17(1), 1-30. https://doi.org/10.1080/09645290802028315

Rahman, A. A. (2016). Metode Penelitian Psikologi. PT Remaja Rosdakarya.

Siregar, S. (2019). Statistik Parametrik untuk Penelitian Kuantitatif. Bumi Aksara.

Sugiyono. (2015). Metode Penelitian Pendidikan. Alfabeta. 
Susilowati, L., \& Wahyuni, D. (2019). Pengaruh Upah Minimum terhadap Penyerapan Tenaga Kerja Bidang Industri di Indonesia. Jurnal Ekonomi-Manajemen-Akuntansi, 15(2), 222230.

Utami, Y. G. D., \& Hudaniah. (2013). Self Efficacy dengan kesiapan kerja siswa sekolah menengah kejuruan. In Jurnal Ilmiah Psikologi Terapan (Vol. 1, Issue 1, pp. 40-52).

Verma, P., Nankervis, A., Priyono, S., Saleh, N. M., Burgess, J., \& Connell, J. (2015). Graduate work-readiness in the Asia-Pacific region: Perspectives from stakeholders and the role of HRM. Equality, Diversity and Inclusion: An International Journal, 37(2), 73-89. https://doi.org/10.1108/EDI-02-2016-0016

Wardani, E. S. (2018). Wardani (2018).pdf. Journal of Mechanical Engineering Education, 3(2), $101-110$.

Wijayanti, S. F. S. (2019). Pengaruh Modal Psikologis, Kompetensi Karir, dan Dukungan Sosial terhadap Kesiapan Kerja. Skripsi. Universitas Islam Negeri Syarif Hidayatullah Jakarta: Fakultas Psikologi.

Xanthopoulou, D., Bakker, A. B., Demerouti, E., \& Schaufeli, W. B. (2009). The British Psychological Society Work engagement and financial returns: A diary study on the role of job and personal resourcess. In Journal of Occupational and Organizational Psychology (2009), (pp. 183-200). 